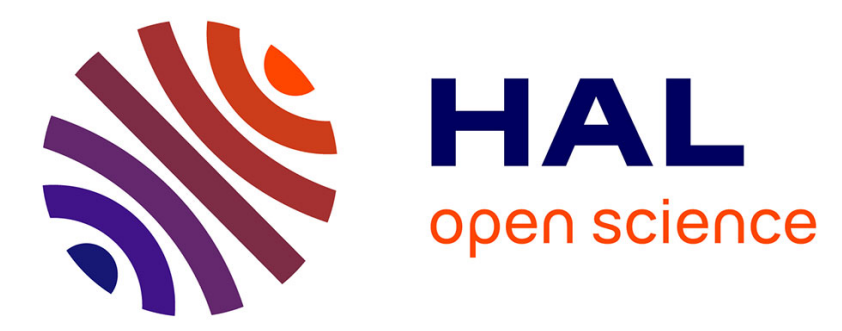

\title{
Whiteness, multiculturalism and nationalist appropriation of Celtic culture: the case of the League of the South and the Lega Nord
}

\author{
Euan Hague, Benito Giordano, Edward H. Sebesta
}

\section{- To cite this version:}

Euan Hague, Benito Giordano, Edward H. Sebesta. Whiteness, multiculturalism and nationalist appropriation of Celtic culture: the case of the League of the South and the Lega Nord. cultural geographies, 2005, 12 (2), pp.151-173. 10.1191/1474474005eu316oa . hal-00572141

\section{HAL Id: hal-00572141 \\ https://hal.science/hal-00572141}

Submitted on 1 Mar 2011

HAL is a multi-disciplinary open access archive for the deposit and dissemination of scientific research documents, whether they are published or not. The documents may come from teaching and research institutions in France or abroad, or from public or private research centers.
L'archive ouverte pluridisciplinaire HAL, est destinée au dépôt et à la diffusion de documents scientifiques de niveau recherche, publiés ou non, émanant des établissements d'enseignement et de recherche français ou étrangers, des laboratoires publics ou privés. 


\title{
Whiteness, multiculturalism and
} nationalist appropriation of Celtic culture: the case of the League of the South and the Lega Nord

\section{Euan Hague, Benito Giordano and Edward H. Sebesta}

Geography Department, DePaul University

School of Geography, University of Manchester

Independent scholar

\begin{abstract}
The League of the South (USA) and Lega Nord (Italy), formed in 1994 and 1991 respectively, are nationalist organizations that have utilized claims to Celtic ethnicity to further their appeal. In this article we explore these claims, made in relation to the southern United States and northern Italy, and argue that they are used by these organizations to justify exclusionary politics. By claiming a privileged status for Celtic culture, heritage and genealogy, the League of the South and Lega Nord envision their putative nation-states as accommodating other ethnic groups in subordinate roles. We argue that claiming Celtic ethnicity is an implicit appeal to white privilege. In the proposed nationstates of the Confederate States of America and Padania, white authority would be sustained. Further, the way these groups use Celticness allows them to make links to specific historical and material geographies. Claiming Celtic origins enables northern Italians to distinguish themselves from southern Italians, and to make an associated historical-geographical connection between themselves and northern Europe, enabling disassociation from the Mediterranean. The League of the South claim to 'Anglo-Celtic' ethnicity enables their membership to distinguish themselves from other residents of the United States, be these non-white residents of the southern states or other white people within the USA. Finally, we suggest that some dominant political commitments to multiculturalism facilitate precisely such claims to Celtic origins, however tenuous, to be made in the name of recognizing and protecting cultural difference.
\end{abstract}

$\mathrm{O}$ n 18 September 2000 the Guardian newspaper in the UK contained articles about two nationalist organizations that emerged in the 1990s, the Lega Nord (LN) in Italy and the League of the South (LS) in the US. ${ }^{1}$ There were several reasons for this press coverage. A week previously, the League of the South had been identified as a 'hate group' and part of a 'neo-Confederate movement, increasingly rife with white supremacists and racist ideology [that] is growing across America'. ${ }^{2}$ The Lega Nord 
had decided to re-establish a political alliance with the centre-right coalition for the May 2001 Italian general election, a somewhat surprising move because in 1994 the Lega Nord had left Silvio Berlusconi's short-lived governing coalition, causing its collapse. ${ }^{3}$ Despite differences between the Lega Nord and League of the South, the former being part of the Italian government and the latter a fringe organization without elected officials, both movements share similarities and, recognizing these, have established formal connections. Such sentiments resulted in a joint conference between the leading members of the Lega Nord and the League of the South at Lake Como, Italy, in May 2000. In 1996, a director of the League of the South explained the ties between the two groups:

The Southern League [League of the South $]^{4}$ has more in common with Italy's Lega Nord (Northern League) than just a name. Umberto Bossi and his followers cherish the same dreams of limited self-government advocated by the League, and they are making a determined effort to take back control of their lives, their culture, and their heritage from a corrupt central government. ${ }^{5}$

This paper examines the League of the South and makes preliminary comparisons with the Lega Nord as these two contemporary nationalist movements emerged at similar times with analogous proposals for the establishment of independent nation-states. We argue that recognition by the Lega Nord that Celtic origins are central to their proposed nation of Padania correlates with the demands for an 'Anglo-Celtic' Confederate States of America (CSA) suggested by the League of the South. The respective assertions of Celtic heritage arguably comprise attempts to recruit support and legitimate political demands for secession.

A comparison between the LS and the LN is illuminating, as it affords the opportunity to consider how such organizations are using appeals to cultural protection and difference to bolster claims that they represent a distinct ethnic group deserving of selfdetermination and an independent nation-state. Located within different geographical and political contexts, the League of the South and Lega Nord both developed their strategies of appealing to Celtic culture within currently popular inclusionary discourses of multiculturalism. Although the political project and discourse of multiculturalism varies over time and space, in US and many European discourses of multiculturalism one of the base tenets is an essentialized understanding of culture. ${ }^{7}$ People are envisioned by policy-makers as belonging to singular and bounded cultures and, consequently, supposed cultural differences become the basis for the evaluation of all difference, and hence constitute the defining component of entitlement to status and authority. This becomes a way of writing ethnicities and cultures as the fundamental bases of contemporary Western society, typically eliding other structuring elements such as gender, sexuality and class. It also demands that claims to political power and legitimacy can only be made through appeals to cultural distinction and an assertion that one culture is as valid and worthy of status as any other. Consequently, material geographies of power become structured by such cultural claims as activists justify their control of resources through symbolic geographies of culture and ethnicity. The results are current Western political conceptualizations of multiculturalism that try to balance recognition of cultural distinction with a commitment to the commensurability of all cultures: 
multiculturalism's simultaneous assertion of the right to be different and to be treated equally is inherently problematic. It can also be in tension, if not contradiction, with the central tenets of liberal democracy. ${ }^{8}$

It is this point of tension within current liberal democratic practices of multiculturalism in Western Europe and the United States that members of groups like the LS and LN can exploit. By appealing to cultural distinction and the right to be different, they can demand that the people they represent deserve what they envision as protection from cultural erasure and homogenization. Typically, claims to culture are increasingly used by groups to assert rights to political power or maintain their privileged status within the existing political economic system. ${ }^{9}$ In contrast, as nationalist organizations, the LS and LN appeal is not confined to extant structural relationships. Rather, the LS and LN want to impose new political and economic relations by establishing new nation-states. In these independent nation-states, authority to empower people will rest within new political structures. In Padania and the CSA, therefore, LN and LS supporters would establish themselves as the dominant group; and, as we demonstrate below, those cultural groups conceived of as having different ethnic ancestries from those of the ruling class would be subordinate.

The LS and LN exploit a version of popular sentiment that envisions a direct relationship between culture and territory, with each ethnic culture retaining $a$ priori a right to possession of a particular territory which constitutes a bounded homeland. ${ }^{10}$ Articulating cultural distinction is, therefore, one of the symbolic and discursive strategies through which nationalist activists recruit followers and demand the power to control certain demarcated territories. LS and LN claims to Celtic ancestries and proposals to disaffiliate from the United States and Italy and establish independent nation-states may appear far-fetched. Yet our comparison, focusing on each organization's appeals to Celtic origins, demonstrates how political activists are appropriating cultural identity as a basis for repositioning their claims to ethnic authority and control over territory.

\section{Why Celtic? Why now?}

'Celtic identity politics', argue Harvey et al., experienced an 'energisation' in the late twentieth century, primarily in the British Isles, where successful Scottish, Welsh and Northern Irish campaigns for devolution generated a restructuring of British political and institutional relationships. ${ }^{11}$ Celticity, Harvey et al. proceed to remark, comprises an attractive set of symbols and identities that come replete with popular recognition and a supposedly ancient past that can be invoked by people for many purposes, from 'new age' religion to popular 'world music'. ${ }^{12}$ Through interest in genealogy and the marketing of popular Celtic culture, Celticity was exported beyond the British Isles. Two areas in which nationalist activists pursued interest in Celtic cultural identity were the southern United States and northern Italy, locations not usually associated with Celtic separatism.

The very flexibility of Celticity and the vagaries of archaeological evidence regarding the original Celts enable multiple political and cultural meanings to be invested in the 
term, whilst retaining both the symbolic value and historical authority accrued by reference to a supposedly ancient Celtic culture. As Chapman and James have demonstrated, Celtic culture and identity has problematic historical foundations. ${ }^{13}$ Since the eighteenth century, the archaeological record has been interpreted as evidence for 'a prehistoric Celtic commonwealth stretching from Scotland to Portugal and Turkey', and confirmation of a singular, pan-European, Celtic culture. ${ }^{14}$ Such a reading, although popular and commonly reiterated, is founded upon simplistic assessments of burial styles and metal working designs, and on an assumption of cultural uniformity over time and space in the Bronze and Iron Ages. Indeed, Trumpener explains that at least since the mid-eighteenth century, claiming Celtic origins has enabled people 'to fabricate whatever version of the past seemed nationally expedient'. ${ }^{15}$ Despite such flexibility, Celts are commonly envisioned as white people, coming from areas of northern and central Europe that are historically associated with white populations. This racialization of Celtic identity, discussed below, is another component enhancing the desirability of Celtic culture for the Lega Nord and League of the South.

Although Celtic history is disputed, its geographies are less malleable. Territory associated with Celtic inhabitants is generally agreed to be European, and is most commonly associated with the non-English areas of the British Isles, namely Ireland, Scotland, Wales and the Isle of Man. The south-western English county of Cornwall is also often included in popular accounts of areas inhabited by Celts. Other regions include Brittany in France and Galicia in northern Spain. ${ }^{16}$ These predominantly northern European geographies locate Celtic peoples and culture within the territories of modern dominant political and cultural powers. They are also areas of Europe that have long been seen as occupied by white populations. ${ }^{17}$ Further, in the 1990s, the context of developing a single European market and political community led to attempts to establish Celts as a pan-European people and an ancient example of European political and economic unification. ${ }^{18}$ These efforts were focused on the exhibition The Celts: the origins of Europe, which ran from March to December 1991 in the Palazzo Grassi, Venice. A massive catalogue for this exhibition contained essays that recognize Celtic peoples and culture in Europe extending from the Atlantic coasts of Ireland and northern Spain, to Poland, the Balkans, Greece and Turkey. ${ }^{19}$ The volume also identified a revival of interest in Celtic culture and archaeology within Italy in the late 1970s and early 1980s, precisely the period in which immigrants first arrived in Italy in significant numbers. ${ }^{20}$

In the United States, the meaning of Celtic culture and identity has undergone a transformation in the 1990 s, becoming a hugely popular commercial product. An association of Ireland with political conflict, Casey argues, has been replaced by a 'barrage of Irishness on supermarket shelves', and an image of fun and revelry appealing to an estimated market of 40 million consumers. ${ }^{21} \mathrm{~A}$ similar transformation has occurred with Scottishness, not least due to the success of the 1995 film Braveheart. ${ }^{22}$ In the 1980 US Census, Scottish ethnic ancestry was 'very unpopular', but two decades later Diane Roberts contended that Scottish culture had 'muscl[ed] Irishness out of the way as the Celtic flavor $d u$ jour' in the USA. ${ }^{23}$ With the growing 
popularity of Irish pubs, Celtic music and films like Braveheart, identification with Celts is arguably at an all-time high in the United States.

Such strong assertions of Celtic ancestors is a recent phenomenon in the USA, where in the nineteenth century popular culture deplored the Irish in particular as members of a distinct and inferior Celtic race. Celtic identity 'became white', losing its prior ascription as a subordinate cultural and racial identity, as Celtic immigrants assimilated into mainstream US political and economic structures and were replaced as low-wage labour by African-Americans moving north and into factories in the early twentieth century. ${ }^{24}$ Irish culture and ethnicity in the United States, Arndorfer argues, is a product of an '[u]nspoken but always understood... contrast... with that other major, if more threatening, exotic group in the United States: African-Americans'. Such assessments lead Hague to argue that for some adherents in the United States 'Celtic' culture is synonymous with 'white racial identity'. ${ }^{25}$

\section{Celtic identity and multiculturalism}

Current claims to Celtic culture and identity by the LS and LN operate within a contemporary political climate which advocates multiculturalism as the basis of Western democracies at the start of the twenty-first century. Multiculturalism can, therefore, be recognized as a discourse and political commitment that developed in a specific historical context. Stephen Castles, amongst others, argues that political discourses and struggles about multiculturalism are thus intertwined with late-twentieth-century practices of immigration and processes of social and economic restructuring. These trends are reshaping institutional structures such as the state, national community and supposedly homogeneous cultural traditions. ${ }^{26}$ Within these processes, Castles maintains, immigrants and ethnic minorities defend themselves against racism and marginalization originating within the host society - typically from those residents most affected by these restructuring processes, who are predominantly male and white - by asserting their 'right to cultural difference' within a multicultural population. ${ }^{27}$ This leads to appeals by the marginalized for authorities to recognize, protect and respect cultural differences. LS and LN appeals to Celtic ancestry, made within this contemporary political context of multiculturalism and recognition of cultural difference, are, however, partially a nativist response to immigration and shifting structures of political power. For example:

The Southern League [League of the South] envisions a South where our borders are sealed against massive Third World immigration; a South where the interests of the core population of Anglo-Celts is protected from the ravages of so-called multi-culturalism and diversity; a South where a prosperous and self-confident European majority can welcome into its ranks on its own terms productive and sympathetic members of other nations and cultures. ${ }^{28}$

The 'right to cultural difference' is, in the case of the League of the South, asserted as a reaction against multiculturalism, yet the LS utilize rhetoric of cultural protection to justify their political demands. Arguing that proponents of 'Anglo-Celtic' culture have 
been too timid in the face of multiculturalist doctrines, LS president James Michael Hill identifies the need to reassert their 'Anglo-Celtic' culture as the most significant part of the landscape:

The multicultural diversity crowd has thus far managed to cow us into apologetics or outright silence. Presently, our Anglo-Celtic Southern culture and its history, heroes, songs, symbols, and banners are under attack, and their defence could serve as our immediate rallying point ... Only if we know who we are and whence we have come can we hope to survive and prosper as a distinct people. ${ }^{29}$

In some contexts, therefore, the tensions within multiculturalist ideology between recognizing difference and safeguarding cultures can become a justification for segregationist sentiment, as the League of the South make clear:

The League of the South upholds the right of free association. Peoples of different cultures should pursue their own interests without interference from bureaucrats and social engineers who push such enormities as global democracy and multiculturalism. ${ }^{30}$

The integrationist rationale of multiculturalism is envisioned by the LS (and the LN) to threaten the distinct cultural practices that proponents envision as defining their group identity. Such segregationist assertions of 'distinct people' and 'own interests' can be exploited by activists who demand the return to prior structural conditions in which their group enjoyed political supremacy and power, implicitly calling for the disempowerment of those whom they perceive to be benefiting from current multiculturalist practices. To achieve this desired goal, and with it their supposedly rightful status of dominance, both the LS and LN propose secession and the establishment of independent nation-states. Recognizing current political discourses, both the LS and LN demand that Celtic culture, and by extension the culture of those with Celtic ethnicity and ancestry, should be self-determined. This 'right to cultural difference' for the LS and LN becomes a basis upon which wider political strategies can be founded. A claim of right to self-determination for those exhibiting Celtic ethnicity is for LS and LN activists a claim to power, territory and control. Exploiting the tensions between multiculturalist recognitions of difference and commitments to sustaining a multiplicity of cultures, the LS and LN use Celtic ethnicity as a strategy to broaden their potential audience, widen their appeal and assert their cultural right to power. The result, as we demonstrate here, is 'a politics of separatism'. 31

\section{Multiculturalism and whiteness}

In the 1990s the activists who founded the League of the South and Lega Nord were able, we suggest, to assert their recovered Celtic origins because of the discursive resources made available by the growing popularity of Celtic-themed popular culture, mainstream political commitments to multiculturalism and the resurgence of nationalist separatisms in post-Soviet Eastern Europe. Celtic culture, long incorporated into whiteness in the United States, could be appropriated and reinscribed as a progressive cultural identity - equivalent to established European nationalist groups in Scotland, Ireland and Wales, while allowing implicit appeals to white superiority to remain 
unstated. Recasting a politics of white superiority as a Celtic nationalism committed to preserving the ancient Celtic culture and attaining a homeland territory enabled adherents to rearticulate their beliefs through well-established political discourses of cultural protection and the right to self-determination. As claims to whiteness have become the preserve of overtly racist political groups, we maintain that discourses of Celtic culture and identity made by the LS and LN implicitly appeal to racial constructions, albeit hidden behind a veil of Celticity. This occurs in much the same way as 'discourses of Englishness', which, Peter Jackson argues, 'draw on a construction of "whiteness" that is socially significant, though rarely expressed openly in public, ${ }^{32}$

Multiculturalism in its current form can be used both progressively by some for a greater stake in society and regressively, to empower dominant sections of the population via recourse to identifying their supposedly authentic cultural identities which are deserving of sustenance. One consequence of this is a linguistic convergence between political left and right in their articulations of culture which is seen primarily, if not solely, as a product of ethnicity. Progressive agendas and those of the 'racist right', although wholly at odds in their projects and desired outcomes, both 'infuse the race or ethnic category with essentialist, and supposedly naturally inherited, characteristics'. ${ }^{33}$ Appeals to the 'right to cultural difference', therefore, can be used by activists to reclaim an ethnic identity that is argued to have been struggling against erasure within homogenizing mainstream doctrines, and to articulate claims to power and long-subordinated rights to self determination. From here, multiculturalism does not have to be stretched too far to be used to racialize people, because in popular assessment,

Identifications with nation-states are built by definitions of peoplehood rooted in concepts of descent. People who share common cultural attributes are assumed to share a common biological heritage or people who share a particular line of descent are assumed to hold cultural characteristics in common. ${ }^{34}$

Rather than direct appeals to race or biology, a multiculturalist discourse can be used by political activists to appeal to cultures which form the basis of modern political groupings. The political right, therefore, can reposition themselves as defenders of culture and heritage, uniting a commitment to the recognition of cultural difference and distinctiveness with assertions of the need to retain political control. Vindicating their separatist agendas by appealing to historical ethnic distinctions, the League of the South and Lega Nord locate their separatist politics within current US and European political discourses of multiculturalism in which recognition of a diversity of ethnic and cultural groups is officially promoted. Hague posits that in the United States, in place of the idea of a 'melting pot', pre-eminence is increasingly given to one's ethnic identification as defined by genealogy. ${ }^{35}$ This facilitates and implicitly sanctions a process of 'ethnic claims-making' which, Mitch Berbrier argues, enables 'new racists' to represent white supremacist ideology through claims of belonging to an ethnic group:

new racists argue that if, according to the values of 'cultural pluralism' and 'diversity', ethnic or racial pride is legitimate for (other) ethnic or racial minority groups... then it is also legitimate for whites. 
This 'new racist' discourse in the United States, Berbrier demonstrates, centres on an appeal to the 'equivalence' of all ethnicities and an argument that all cultural heritages are worthy of preservation. ${ }^{36}$ Consequently, groups like the LS and LN are "taking the opportunity to construct out of a multiculturalist agenda of tolerance... balkanization and intolerance'; ${ }^{37}$ and, as Hobsbawm and Kristeva suggest, these nationalist calls to ancient ethnic identities and enduring cultures are fundamentally exclusionary. ${ }^{38}$

Claims to culture can be positioned as timeless and unchanging, bounded by ancient history and genealogical lineage. The LS and LN are organizations that, we suggest, recognize the strategic political worth of such appeals to Celtic ancestry to recruit supporters, and may well believe in the historical Celtic culture of the people residing within the territories they claim as the CSA and Padania. Our intention here is not to debunk the appeals of LS and LN claims to Celtic pasts, nor show how they are historically inaccurate. Rather, we argue that these claims to Celtic ancestry are efforts to use assertion of cultural distinction to reposition the meaning of being white within contemporary political discourses of multiculturalism in the USA and Italy, and subsequently to use this to assert a right to political authority and institutional control over people and territory.

\section{The League of the South}

Politically conservative, and advancing what it envisages as an 'orthodox Christianity' as the basis of its policies, the League of the South ${ }^{39}$ was founded in Alabama in $1994 .{ }^{40}$ Growing to around 10000 members by 2002, the organization advocates secession for 15 states: the 11 Confederate states that withdrew from the USA causing the 1861-65 Civil War plus 4 others. ${ }^{41}$ James Michael Hill, a historian and LS president since the group's foundation, explains: 'The League of the South is a Southern nationalist organization. It believes in preserving Southern heritage and culture, believes in states' rights, believes in Southern independence. ${ }^{42}$ The League of the South is part of a wider neo-Confederate movement in the United States which encompasses peripheral groups such as Free Mississippi and the Southern Party, the more mainstream heritage organizations Sons of Confederate Veterans (SCV) and United Daughters of the Confederacy (UDC) and, most infamously, the former leader of the US Senate, Republican Trent Lott. Neo-Confederate ideology intertwines a range of political thought, theology and historical interpretation into a call for recognition of a specific Southern US culture and various assemblages of what that culture means for the control of people and resources. Many neo-Confederates argue that to uphold this distinctive 'Southern culture', secession of the CSA from the United States is necessary. Horwitz, in his account of current invocations of Confederate heritage in the United States, explains that central to neo-Confederate ideology is a claim that in the nineteenth century,

North and South went to war because they represented two distinct and irreconcilable cultures, right down to their bloodlines. White Southerners descended from freedom-loving Celts in Scotland, Ireland and Wales. Northerners - New England abolitionists in particular - came from mercantile and expansionist English stock. ${ }^{43}$ 
This understanding of US history, often identified as the 'Celtic thesis' of the US South, originated in scholarly work in the 1970s-1980s by academic historians who became leaders of the League of the South upon its establishment in 1994, namely James Michael Hill and Grady McWhiney. Tracing the ancestral connections of people in the US South to Celtic areas of the British Isles in a series of academic articles and books, and drawing on the work of cultural geographers such as Terry Jordan, ${ }^{44}$ McWhiney and colleagues argued the US South was a distinctively Celtic region with a Celtic population. ${ }^{45}$ This enabled proponents to argue that residents of the southern United States embodied a different culture from that of the northern states, and that the American Civil War was basically a continuation of the centuries-old conflict between Celts and Englishmen'. ${ }^{46}$

Assertions of the Celtic thesis were widely reported, attracting comment in the mass circulation magazine Newsweek. ${ }^{47}$ Academic debate, challenge and criticism followed, ultimately resulting in rejection of the Celtic thesis as 'ten years insistence on the selfsame deductions from untenable premises' ${ }^{48}$ In their accounts, McWhiney, Hill and their colleagues were inconsistent in the identification of regions and peoples of Europe as being ethnically and culturally Celtic. The US historian Rowland Berthoff, for example, rejected the 'expanded concept of a perdurable Celticness', used by proponents of the Celtic thesis, arguing in 1986 that McWhiney's definition of Celtic 'follows no known usage'. ${ }^{49}$ Other academic critics also noted that advocates for the Celtic thesis conceived of culture in much the same manner as nineteenth-century racial taxonomists. Sheehan, for example, commented that the writing of future LS president Hill "smacks strongly of pseudo-scientific Victorian notions of "races" and "racial characteristics". ${ }^{50}$ Despite such challenges, in the late 1980s the right-wing conservative organization the Rockford Institute reiterated the contention that the US South was, and implicitly is, Celtic in its Chronicles magazine. ${ }^{51}$ LS authors suggest, therefore, that Celts constitute a stateless people whose efforts to establish nation-states have been consistently thwarted by superior imperial powers. Roman, British and federal US Union troops defeated Celtic aspirations in what McWhiney identifies as the three climatic battles in Celtic history: Telamon [225 BC, Italy], Culloden [1746, Scotland] and Gettysburg [1863, Pennsylvania],.$^{52}$ This lengthy history of Celtic peoples adds weight to LS demands that self-determination is overdue. These contentions form the basis of LS insistence that the US south is a Celtic homeland in which Celtic culture comprises 'core' elements of CSA national culture. Michael Hill explains:

[T]he present-day South is the remnant of a nation built on the realities of place and kin that we must revitalise to the best of our abilities. At its core is a European population, especially Anglo-Celts, that must be preserved as the dominant majority. ${ }^{53}$

In LS political discourse, 'Anglo-Celts' refers to English speaking people of Celtic ancestry, as director of the LS Mississippi chapter Barry Reid McCain clarifies:

The Anglo prefix merely signifies use of the English language, a useful classification because there are still several native Celtic languages that have survived into modern times. While Anglo-Celt can apply to many people in the British Isles and large parts of the population of various ex-British colonies, it is the [US] South where Anglo-Celts established a homeland and have retained many of their core cultural traits. ${ }^{54}$ 
Further, on a radio programme broadcast throughout the USA, Hill declared that the US South was engaged in a cultural struggle, and that 'the element of Southern culture that is under assault is what I like to call the white Anglo-Celtic'. ${ }^{55}$ This Anglo-Celtic culture is constructed in opposition to what the League envision as the normative US culture, which, basing their assessments on the tenets of the Celtic thesis, is founded upon English origins. Consequently, the League of the South can distinguish their constituency, namely white people exhibiting Anglo-Celtic culture, from other white people in the US, who are identified as 'Anglo-Saxon' and thus constitute a different ethnicity and culture. In LS reasoning, different cultural groups should each be allowed political autonomy and self-determination. ${ }^{56}$ Asserting Anglo-Celtic culture is, therefore, a LS strategy to position the white Southern population as culturally distinct from other white people in the USA, and thus as entitled to residence in and control over a separate nation-state - the CSA.

The League of the South envision the United States as an imperial power which exhibits an anti-Christian vulgar and materialist culture, which the LS leadership considers to be depraved. ${ }^{57}$ Utilizing a strategy of building support for their secessionist plans from the bottom upwards, advocating home schooling, peer group education and local Confederate heritage activism, the LS intend to empower local communities and thereafter define their own codes of law and morality, severing ties with what they envision as tyrannical US federal and Supreme Court rulings. Their agenda, much of it theologically driven, is also strongly patriarchal and heterosexist - topics beyond the scope of the current article, though important for future analysis. At the basis of the LS assertions of 'Anglo-Celtic' ancestry are assumptions of nativism and white privilege. Arguing that people of European descent, particularly Anglo-Celts, are at the centre of southern US culture and population necessarily downplays the presence, impact and rights of other ethnic groups and peoples in the 15 states claimed by the League as the CSA. People of Hispanic descent are classified as immigrants and illegally present in the United States. According to LS director Clyde Wilson, a professor of history at the University of South Carolina, an independent CSA would not tolerate the presence of Hispanic people:

In the new Confederacy, unlike the U.S., we wont $[\mathrm{sic}]$ have a bit of difficulty telling the difference between a citizen and an illegal alien. We can hope that the problem will be easily solved and that Smyrna, Georgia, and Siler City, North Carolina, will no longer be outposts of Mexico. ${ }^{58}$

As the non-white population in the United States rises, the struggle over immigration is simultaneously over the power to control territory and people. The League of the South envisions their putative nation-state as one where ethnicity and culture avows citizenship. Full citizenship could not be attained by residency or birth within CSA territory but, it seems, by 'Anglo-Celtic' ancestry. Current US political and economic structures, responding to the needs of capitalism, have enticed cheap labour to move to locations like rural North Carolina and Georgia. This labour is typically embodied by non-white persons participating in low-income employment in industries such as poultry processing. ${ }^{59}$ Reacting to these changes, and feeling threatened by the growing presence and politicization of non-white groups, the LS appeal to the need to protect 
'Anglo-Celtic' heritage, namely white superiority and patriarchal, heterosexist authority, in the face of changing demographics which, in some areas of the southern United States, will soon see majority non-white populations.

Trying to avoid overtly racist statements, the LS typically proposes that non-white residents will remain in an independent CSA, but that the status, numbers and rights of these non-whites will be restricted. ${ }^{60}$ Consequently, the white population will remain 'dominant' and in a position of institutional control:

Blacks make up about a quarter of the South's population, a demographic fact that cannot be ignored. Therefore the relationship between Southern whites and Southern blacks must be approached in a realistic manner, and 'tribal homelands' are anything but realistic...

Each time the League leadership addresses itself to the issue of race, the policy we advance must be free of hatred and malice. This has been our position from the start. Though many blacks may be taught to hate us in their homes and institutions, our response to them must be grounded in Christian charity ... This does not mean, however, that we must subscribe to the flawed Jacobin notion of egalitarianism, nor does it mean that white Southerners should give control over their civilisation and its institutions to another race, whether it be native blacks or Hispanic immigrants. Nowhere, outside of liberal dogma, is any nation called upon to commit cultural and ethnic suicide...

Let us in the League, then, confidently defend our ethnic, cultural, and religious heritage. After all, we have as much right to do this as anyone. ${ }^{61}$

In his analysis Hill envisions a distinction between white and non-white populations in the southern US states, outlining this as 'us' and 'our' response to 'them' and 'their' beliefs. Writing to his supporters in this passage, Hill's perception of the racially white composition of LS membership is evident. He recognizes the presence of non-white people in the southern US states, but notes that this is not grounds for 'control' over cultural and political institutions by groups other than the 'white Southerners'. Indeed, to cede power would, for Hill, result in the self-inflicted destruction of white privilege and power, something which he ascribes to current progressive multiculturalist politics. Yet, softening his rhetoric, he then appeals to the very same discourses of multiculturalism, arguing that the white Anglo-Celtic population who constitute the League of the South's membership are merely sustaining their heritage and tradition, something to which they are as entitled to do as any other cultural group.

One of the problems with current US invocations of cultural rights for all, note Bulmer and Solomos, is that through appeal to 'the defence of a given cultural identity', the reactionary politician can utilize multiculturalism to assert 'the superiority of one group over another'. ${ }^{62}$ Comments by Hill and other League of the South leaders are equitable to the 'separate but equal' rhetoric of the segregation-era United States. Rather than brutish white supremacism, however, the League of the South reworks and repositions whiteness as 'Anglo-Celtic' ethnicity, and emphasizes that current Celtic cultural inheritances in the US South are largely indistinguishable from those of ancient Celts. ${ }^{63}$

In the United States, appealing to Celtic ancestry and arguing that it deserves political recognition and power could attract adherents, particularly white men feeling threatened by the outcomes of multiculturalist policies, to the League of the South's cause. Our analysis of these statements demonstrates how League of the South leaders 
assert the right of white people (again primarily men) to dominate and control people and territory in a putative Confederate States of America through a conduit of claiming Celtic cultural heritage. This demand is grounded both in the language of multiculturalist discourse, which advocates that all cultural groups are worthy of protection, and in an assertion that the 'Anglo-Celtic' peoples of the proposed CSA have prior claim to cultural and institutional dominance, partly as a consequence of the antiquity of Celtic peoples. Claiming Celtic ancestry enables the League of the South to assert that this ethnicity has long been denied its rightful condition of an independent nation-state with an autonomous homeland. Having identified the southern US states as the location where the Celts have 'established a homeland', LS officials make claims to control the area and people in it through an embodied set of cultural rights. In the 1990s it was not only the League of the South that was claiming Celtic origins as the basis for their politics of secession. In Italy, the Lega Nord, considerably more successful in elections than the LS, made similar demands and it is to this we now turn.

\section{The Lega Nord}

The Lega Nord ${ }^{64}$ was founded in 1991, when a number of regional groups combined under the leader of the Lombard League, Umberto Bossi. A prominent and controversial figure in Italian politics, Bossi has led the Lega Nord since its establishment. The Lega Nord argues that residents of northern Italy are impinged upon by a corrupt central government which favours southern Italy and its inhabitants. Bossi's rhetoric, skilful at times and overtly racist at others, was initially successful in 1992, when the Lega Nord received three million votes ( 8.7 per cent) in national elections. The party gained further support as a result of the tangentopoli ('kick-back city') scandals of 1992-4 that damaged the credibility of Italy's main post-Second World War political parties. The LN subsequently entered government as part of Prime Minister Silvio Berlusconi's coalition. Berlusconi managed, however, to play on southern Italian fears of the Lega Nord's politics, and effectively prevented the expansion of the Lega Nord's appeal. Retreating from government and seeing their support decline, in 1995 the LN repositioned itself by endorsing the secession of 'Padania' from Italy and advocating the rights of people exhibiting Celtic culture and ancestral identities. For the $\mathrm{LN}$, this interaction between claims to territory and culture is complex because, as Agnew and Brusa contend, although 'territory matters crucially to the political imaginations of the Lega', from the LN's perspective, 'territory defines a culture associated with a myriad of northern Italian localities rather than a homogeneous "Padanian" culture defining a "Padanian" territory'. ${ }^{65}$ Thus claims to land that would constitute Padania intersect with claims to culture, and operate in tandem to reinforce a sense that the genealogy and geography of Padania are fundamentally intertwined.

A central element in LN political discourse is distinguishing between Padania and the rest of Italy. Utilizing anachronistic stereotypes of southern Italy, the LN controversially represents and reproduces anti-southern sentiments. Although this is a major reason for the growth and political success of the party in northern Italy, it has also resulted in the 
LN being seen as racist and opposed to Italian national unity. Anti-southern sentiment recurs throughout the LN's political project, and is manifested in numerous ways. The most prevalent are the articulations of what the LN argues constitute cultural differences between northern and southern Italy. Although the LN appeals to a cultural rather than biological differentiation, Bull argues that this process does, however, have a racist subtext which attributes negative characteristics to southern Italians ('mafiosită') and foreign immigrants. ${ }^{66}$

According to the LN, economic differences between northern and southern Italy are consequences of different cultures. Northern Italy, maintain LN leaders, is geographically close to northern Europe, which supposedly produces a culture built around a core set of values and behaviours. These include a strong work ethic, entrepreneurship, a spirit of sacrifice, a high propensity to saving money, trust, solidarity, and lawabiding behaviour. This is referred to by the LN as 'Lombard neo-Calvinism', and is structured wholly in contrast to the alleged cultural traits of southern Italy, which is consistently portrayed by the $\mathrm{LN}$ as an area in which people have no desire to work and are interested only in claiming state benefits. ${ }^{67}$ For example, a LN local councillor argued:

The mentality of the people of the North is distinct to that of the South. In the North there is a strong work ethic which could be described as almost Calvinistic in nature. In spite of the high levels of taxation and the burden of the South, Lombardy is still one of the wealthiest regions within the European Union (EU). However, the South of Italy has a "Mediterranean" work ethic, which is based on corruption, a reliance on state transfers and a more relaxed attitude towards work. ${ }^{68}$

The LN thus positions southern Italy as 'other' and as a metaphor for all Italy's socioeconomic problems. Although such explanations clearly elide the realities of socioeconomic differences between northern and southern Italy, these LN discourses remain powerful and are advocated by party supporters and activists as correct interpretations of contemporary Italy. To justify Padanian secession from Italy, LN leaders argue that the Italian state has undergone a process of 'southernization' since its creation in 1871. Within LN reasoning, today's Italian identity is actually a southern Italian identity, and is founded upon the supposedly southern values and 'Mediterranean' attitudes which the LN rejects. Consequently, the LN's anti-southern rhetoric rejects Italian nationality, enabling the justification of a different and separate Padanian national identity. This Padanian cultural distinctiveness is argued to need protection from the homogenizing Italian state and its imposition of a singular national culture. Oneto and Pagliarini, for example, argue that the Lega Nord's nationalist campaign is primarily a cultural struggle to maintain Padanian identity and heritage, which are supposedly threatened by the practices of the Italian nation-state:

All of the expressions of the culture of the peoples of Padania are subject to a process of homogenization and a marked Italianization. This is a systematic attempt to break down all of the aspects of our ancient culture, languages, traditions, way of life and institutions. This process is accentuated by people from the south of Italy working in the public administration and schools of Padania. Above all, on the radio and television, southern Italian languages are spoken and only with independence can the peoples of Padania live in complete freedom with their own culture and traditions. ${ }^{69}$ 
Claims to cultural difference and protection are used by the LN, therefore, to legitimate northern Italy as distinct from the rest of the peninsula. Padania and its residents argue LN proponents do not share with other Italians origins, traditions, dialects, cultures or genealogies. Rather, like the League of the South, Celts are identified as a major ancestral group upon which current claims to Padanian cultural difference are founded:

[T]hroughout its history [Padania] has always been able to maintain its freedom and autonomy. First it was the original Lega Lombarda that fought against Frederico Barbarossa and then against Frederico II. We can say that the true unifying force of the people of Padania has been the desire to defend their difference, liberty and autonomy. Padania exists and it is strong and cohesive because it is driven by the ancient aspiration for autonomy, which stems from the demands of its first inhabitants the Celts, the Ligurians and the Venetians to be free. ${ }^{70}$

This quotation, originally on the Lega Nord website, was co-written by Gilberto Oneto, one of the LN's central voices in its campaign to make ethno-territorial claims to northern Italy. Oneto is also responsible for national identity in Padania's so-called governo sole (sun government) and leads the Libera Compagnia Padana (LCP Campaign for a Free Padania). ${ }^{71}$ The LCP promotes and diffuses awareness of Padanian culture and identity by organizing meetings, cultural events and publications such as the twice-monthly journal Quaderni padani (Padanian updates). Oneto's attempts to promote recognition of the historic Celtic residents of Padania are a component in the LN's plan to distinguish culturally between northern and southern Italy on the basis of cultural inheritance and genealogy:

All the peoples of Padania descend from the same original ancestors, which can be categorized into three
principal groups - the first and the oldest are the Ligurians; the second group are the Celts and the
Venetians, which come from diverse areas but have similar cultures and traditions; and the third group are
the Goths, the Longobards and all the other Germanic peoples that inhabited the North of Italy. In contrast,
the ancestors of the Italians are the Etruscans and the Greeks, which were the dominant cultures of the
Italian peninsula. ${ }^{72}$

Oneto and Pagliarini appropriate Celtic peoples as some of Padania's earliest inhabitants to legitimize their claims about cultural differences between northern and southern Italy. These claims are given historical depth and are bolstered by the assertion that Italy has always been ethnically and culturally divided in this manner. Extending this historical claim into the present, these LN supporters argue that residents of the territory they identify as Padania share a common ancestry, implying that residents of this region who do not share these northern European ancestors are not legitimate residents of the region, or at least are not its principal inhabitants. ${ }^{73}$

LN rhetoric and claim to Celtic ancestry serves not only to extenuate Padania's alleged cultural difference from Italy but also to draw a distinction between Padanians and other residents of Italy. Not only does this include those whom the LN believes are descended from Etruscans and Greeks, namely southern European/Mediterranean ancestors, but also non-white immigrants. Assertion of Padania's Celtic and Germanic genealogies is an implicit affirmation of a racially white population as the basis of Padanian culture and identity; and as in the US South, where political economic 
restructuring has stimulated anti-immigrant rhetoric from the LS, so too is antiimmigrant sentiment becoming a dominant theme in LN right-wing populist political discourse. ${ }^{74}$ The LN are particularly concerned by the growing presence in Padania of extracomunitari, 'who originate from certain parts of the world, particularly Arabs from the Middle East and Magrebians', whom, Bossi and Vimercati are convinced, 'do not have the least intention of integrating and accepting our customs'. ${ }^{75}$ Stressing the importance of maintaining the social and cultural integrity of northern Italy, the LN argue that Padania is under threat from both southern Italian immigrants and also from people migrating from outside the EU. According to the LN, extracomunitari immigration has created a set of problems which undermine Padania's supposedly homogeneous culture and social cohesion. As a LN local councillor explained:

The problem is that the extracomunitari often enter Italy illegally and cannot gain legal employment so they often they get involved in crime, drugs and prostitution. The people are not racist but the problem is that the immigrants are coming at a time when the Italian economy is in trouble and so there are not enough jobs for all the Italians, let alone the foreigners. ${ }^{76}$

In much the same manner as LS leader Michael Hill envisages the distinctive 'white Anglo-Celtic' culture of the US South to be under attack from the growing presence and rights of non-white residents and their representatives, the LN sees Padanian culture as threatened by people practising different cultures. Also similarly, the Lega Nord stresses the centrality of maintaining the cultural integrity of Padania in its nationalist rhetoric. At the basis of LN assertions of ethno-cultural autonomy, therefore, is a belief in the inherent right, conferred by prior residence and innate superiority of a supposedly ancient cultural group, to power and control over territory and other people, namely immigrants and southern Italians. By portraying southern Italians and extracomunitari as culturally distinct, not just currently but throughout history, the Lega Nord, in a manner similar to the LS, positions white, native residents of Padania at the 'core' of society in northern Italy.

\section{Claiming to be Celtic: whiteness and multiculturalism}

Theorists of nationalism have long recognized the use of culture in the strategies of nationalist activists to facilitate supposedly ancient connections between a people and a specific territory, an intersection of genealogy and geography. Nationalist leaders typically assert that a culturally defined group of people can be identified, that these people have a right to self-determination and that this self-determination must be spatial, the self-determining people having a legitimate right to control a particular territory. ${ }^{77}$ It is precisely such claims that are used by the LS and LN to assert control over certain territories and their inhabitants, which are then justified by reference to ethnic ancestors and cultural rights. '[C]ommonsense discourse about cultures', argues Tariq Modood, 'assumes each culture has a unique, fixed essence that can be grasped independently of context or intercultural relations, and which makes an ethnic group act the way it does'. ${ }^{78}$ The LS and LN certainly propose essentialized understandings of 
transcendental Celtic cultures within their political strategies, proposing that the permanence and endurance of these cultures since pre-modern times generates legitimacy for separatism.

LS and LN claims to Celtic origins developed in the 1990s during periods of demographic change in the southern United States and northern Italy, when and where immigrants and non-white ethnic minorities were gaining political rights and changing existing structures of power. Leaders of both the LS and LN made statements opposing immigration and promoting nativist claims to territory and power. Declaring Celticness as a primary genealogical identity in the CSA and Padania implicitly subordinates other ethnic groups. Despite their differing contexts, both the Lega Nord and the League of the South nationalist movements engage in political discourses that construct claims to cultural and ethnic distinction. Their usages of Celtic culture are synonymous with privileging a racially white population. As such, these organizations are making retrograde claims to genealogically and racially defined rights to power, but are doing so through rhetorical practices common to contemporary multiculturalist discourses, namely assertion of a 'right to cultural difference'. For the LS and LN, Celtic culture provides an attractive and increasingly marketable imagery upon which to recruit support. That these organizations share a strategy of appealing to Celtic cultural difference as a basis for their secessionist agendas demonstrates a danger of uncritically accepting such seemingly progressive political goals as recognition of multiple cultures. Perhaps most importantly, however, through the utilization of multiculturalist ideas of cultural rights and protection, this appropriation of Celtic culture facilitates the LS and LN with the symbolic and discursive resources to demand that their reactionary racist politics are in fact progressive articulations of heritage and tradition that are worthy of respect and recognition.

In the late 1980s, in locations such as Yugoslavia and the USSR where states were collapsing, "'old-new" national identities', namely new nationalist politics based upon seemingly antiquated origins, were being founded upon 'uncertain genealogies' and 'ethno-history'. ${ }^{79}$ Nationalists engaged in 'cultural wars' to demand recognition for secession, centring upon revered and apparently ancient ethnic identities as a source of cultural authenticity. Soon after, in the early 1990s, Lega Nord and League of the South nationalists appealed to Celtic culture and ethnicity to justify their claims to secession and the control over territory and its occupants. Haylett argues that the end of the twentieth century marks a period when relationships between whiteness and power, although still dominant, are shifting and restructuring. For some white people in some contexts, repositioning within social and political structures is imposed; for example, working-class whites in the UK have been redefined as 'socially excluded' by middleclass multicultural discourse and economic policy. ${ }^{80}$ For other whites in other locations, as Kobayashi and Peake demonstrate in relation to the United States, whiteness remains the normative identity constructed through popular discourse. ${ }^{81}$ In our comparison, members of the LS and LN - both largely middle-class organizations - are working to reposition themselves by claiming a Celtic past, implicitly asserting whiteness as the basis of the right to territorial and institutional power. LS and LN leaders strategically invoke Celtic ethnicity to locate themselves outside the normative whiteness of the USA 
and Italy and thus form a basis upon which to justify claims for self-determination and secession. Further, this claim to Celtic ethnicity enables LS and LN activists to reassert cultural distinction and ethnic segregation by claiming the need for cultural protection.

Multiculturalist discourses and practices of cultural recognition are, on the surface at least, antithetical to racial categorization in that they are supposed to advocate equality of rights regardless of ethnicity or race. Yet, the LS and LN are attempting to gain control over territory, resources and people by strategically advocating cultural distinction and, thereafter, cultural priority and authority. Critically, the nation-states proposed by these two organizations would be embodied by 'dominant' white populations with subordinate non-white residents. Again the advantages of claiming Celtic culture become evident. Unlike 'whiteness,' which has a relatively vague spatial referent, Celtic identities can be placed; definitively located in areas of northern and central Europe. ${ }^{82}$ Archaeological artifacts and historical documents can be invoked to position Celts spatially and temporally. Both LS and LN nationalist activists locate Celtic peoples as the prior residents of their proposed autonomous territories of the CSA and Padania. For these nationalists, because Celts were the primary inhabitants of the territories claimed, those with Celtic ancestry have prior right to reside within and hold power over these areas. The appeal to Celtic culture, therefore, enables the LS and LN to reinforce their whiteness while simultaneously professing to be merely revering their ethnic pasts which, within multicultural discourses, are worthy of recognition, protection and celebration.

Recent assessments of the geographies of white identities have stressed the necessity of recognizing ongoing processes of white privilege and the intersections between whiteness, the constructions of landscape and claims to power, territory, authority and morality. ${ }^{83}$ Such studies demand that geographers propose an antiracist agenda, and contend that the historical and geographical contexts of claims to racial identities are critical to understanding the connections between race and place. Critical analyses of whiteness have demonstrated that this identity is often constituted in relation to other racial classifications. In our case study, Celtic ethnicity and ancestry is used by LS and LN to distinguish themselves from other 'white' groups in the United States and Italy, and from non-white residents and immigrants in these states. Further, in a current political context where direct appeals to whiteness and 'overt race-connected practices' are frowned upon, ${ }^{84}$ an appeal to Celtic ethnicity appears acceptable and can be justified by utilizing a rhetoric of cultural awareness while simultaneously subverting political commitments to cultural equity and reasserting white superiority.

\section{Acknowledgements}

We would like to thank Jim Glassman, Don Mitchell, John Agnew, Carrie Breitbach, Alex Papadopoulos and the three reviewers for their positive and instructive comments that helped us to develop this article. Stephen Castles also kindly provided us with copies of his publications. 


\section{Notes}

1 Duncan Campbell, 'Neo-confederates want out of US', Guardian (18 Sept. 2000); Rory Carroll, 'Northern League's new threat to Italian unity', Guardian (18 Sept. 2000).

2 SPLC (Southern Poverty Law Center), Rebels with a cause, Intelligence Report no. 99 (2000), p. 6. The SPLC are an institution dedicated to monitoring racist organizations in the United States. League of the South president Dr James Michael Hill who also publishes as J. Michael Hill and, most commonly, as Michael Hill, subsequently refuted the SPLC report. Hill describes the SPLC as 'leftist totalitarians' who fail to provide 'a particle of hard evidence to support its accusations and aspersions': see 'Message to the Southern Poverty Law Center And Its Leftist Allies' (2000). Downloaded from http://www.dixienet.org/ls-press-releases/LS-specialreports/splc.htm (29 July 2001).

3 Subsequently, in May 2001, this reformed coalition was victorious, gaining majorities in both lower and upper houses of the Italian parliament, ensuring that the Lega Nord once again held a stake in government.

${ }^{4}$ Following a threat of legal action by a sporting organization that was already using the name, the Southern League became the 'League of the South' in 1997. LS President, Dr Michael Hill explained to members of the organization. 'Your dues are better spent on a cause with a lessthan-perfect name, rather than on litigation that would rob us of our cause while trying to defend an indefensible name' - 'It's in the air', Southern patriot 4 (1997), p. 34.

5 Thomas Fleming, 'From our board ...', Southern patriot 3 (1996), p. 43.

6 The League of the South identify an 'Anglo-Celtic' person as being 'a Celt who speaks English, yet retains Celtic cultural characteristics': Barry Reid McCain, 'The Anglo-Celts', Southern patriot 3 (1996), pp. 35-7. This will be discussed below.

7 Clare Beckett and Marie Macy, 'Race, gender and sexuality: the oppression of multiculturalism', Women's studies international forum 24 (2001), pp. 309-19.

8 Ibid., p. 316.

9 Nina Glick Schiller 'Editor's foreword: the dialectics of race and culture', Identities 1 (1995), pp. iii-iv.

10 Tariq Modood, 'Introduction: the politics of multiculturalism in the new Europe', in Tariq Modood and Pnina Werbner, eds, The politics of multiculturalism in the New Europe: racism, identity and community (London, Zed Books, 1997), pp. 1-25. Chaim Gans, The limits of nationalism (Cambridge, Cambridge University Press, 2003) typifies such an evaluation, asserting the a priori relationship between culture and territorial integrity.

11 David C. Harvey, Rhys Jones, Neil McInroy and Christine Milligan, 'Timing and spacing Celtic geographies;' in Celtic geographies: old culture, new times, ed. David C. Harvey, Rhys Jones, Neil McInroy and Christine Milligan (London, Routledge, 2002), p. 1.

12 See two recent collections: Amy Hale and Philip Payton, eds, New directions in Celtic studies (University of Exeter Press, Exeter, 2000) and Harvey et al., Celtic geographies.

13 Malcolm Chapman, The Celts: the construction of a myth (London, Macmillan, 1992) and Simon James, The Atlantic Celts: ancient people or modern invention? (London, British Museum Press, 1999)

14 Ibid., p. 26.

15 Katie Trumpener, Bardic nationalism: the romantic novel and the British empire (Princeton, NJ, Princeton University Press, 1997), p. 4.

16 John G. Robb, 'A geography of Celtic appropriations', in Harvey et al., Celtic geographies, pp. 229-42. For recent invocations of pan-European Celts, see Sabatino Moscati, Otto Hermann Frey, Venceslas Kruta, Barry Raftery and Miklos Szabo, eds, The Celts (New York, 
Rizzoli, 1991). John Haywood's recent Atlas of the Celtic world (New York, Thames \& Hudson, 2001) identifies Celts as being similarly widespread throughout Europe and covers a timeline of Celtic history from 1200 вс to the 1999 opening of the Scottish parliament. Such publications identifying a Celtic European empire co-exist with analyses, such as those by Simon James and Malcolm Chapman, which question the validity of such claims.

17 Richard Dyer, for example, notes that Romantic writers venerated Scotland as a location where whiteness was at its purest due to the mountainous terrain, climate and remoteness from contaminating non-white bodies. See White (London, Routledge, 1997).

18 Michael Dietler, review of The Celtic world, ed. Miranda J. Green, American antiquity 61 (1996), pp. 611-12.

19 Moscati et al., The Celts.

20 See Umberto Melotti, 'International migration in Europe: social projects and political cultures', in Modood, The politics of multiculturalism in the New Europe, pp. 73-92. Melotti notes that a multi-ethnic population is a relatively recent phenomenon in Italy, dating from the mid-1970s. The first Italian government document on multiculturalism was published in 1991, and by the middle of the decade Italy became 'the EU country with the highest proportion of non-EU immigrants to total immigrants' (p. 87).

21 See recent assessments of Irish popularity in the USA by Reginald Byron, Irish America (Oxford, Clarendon Press, 1999); Jim Arndorfer, 'McSploitation', Baffler 12 (1999), pp. 23-30; Natasha Casey, 'The importance of being Irish-American', Chicago Tribune, (2 Mar. 2003).

22 For discussion of US reactions to and understandings of Braveheart, see Euan Hague, 'Scotland on film: attitudes and opinions about Braveheart', Etudes écossaises 6 (1999-2000), pp. 75-89.

23 For review of the status of Scottish ethnic identity in the US in 1980, see Mary C. Waters, Ethnic options: choosing identities in America (Berkeley, University of California Press, 1990), ch. 2. Diane Roberts, 'Your clan or ours?', Oxford American (1999), p. 24.

24 Matthew Frye Jacobson, Whiteness of a different color: European immigrants and the alchemy of race (Cambridge, MA, Harvard University Press, 1998); Noel Ignatiev, How the Irish became white (New York, Routledge, 1995).

25 Arndorfer, 'McSploitation', p. 26; Euan Hague, 'The Scottish diaspora: Tartan Day and the appropriation of Scottish identities in the United States', in Harvey et al., Celtic geographies, p. 154.

26 Stephen Castles, 'Democracy and multiculturalism in Western Europe', Journal of area studies 8 (1996), pp. 51-76.

27 Ibid., p. 55.

28 Michael Hill, 'Kith and kin', Southern patriot 3 (1996), pp. 33-4. Available at http:// www.dixienet.org/spatriot/vol3no5/prez13.html (accessed 24 Oct. 2003).

29 Michael Hill, 'Extreme traditionalism', Southern patriot 3 (1996). Available at http:// www.dixienet.org/spatriot/vol3no2/prez10.html (accessed 16 Oct. 2003).

30 League of the South, 'The League of the South position: our statement of purpose', League of the South Positon Paper. Available at http://www.dixienet.org/positions/lspositn.htm (accessed 23 Oct. 2003).

31 Martin Bulmer and John Solomos, 'Introduction: re-thinking ethnic and racial studies' Ethnic and racial studies 21 (1998), p. 828.

32 Peter Jackson, 'Constructions of "whiteness" in the geographical imagination', Area 30 (1998), p. 104.

33 Bulmer and Solomos, 'Introduction', p. 825. 
34 Schiller, 'Editor's foreword', p. iii

35 Hague, 'The Scottish diaspora'.

36 Mitch Berbrier 'White supremacists and the (pan-)ethnic imperative: on "EuropeanAmericans" and "white student unions", Sociological inquiry 68 (1998), p. 498-99.

37 Ibid., p. 513.

38 Eric Hobsbawm, Nations and nationalism since 1780: programme, myth, reality (Cambridge, Cambridge University Press, 1990); Julia Kristeva, Nations without nationalism (New York, Columbia University Press, 1993).

39 The League of the South have been reviewed by, amongst others, Diane Roberts, 'A league of their own', Southern exposure 25 (1997), pp. 18-23; Edward H. Sebesta, 'The confederate memorial tartan - officially approved by the Scottish Tartan Authority', Scottish affairs 31 (2000), pp. 55-84; Tara McPherson, 'I'll take my stand in Dixienet: white guys, the South and cyberspace', in Race in cyberspace, ed. Beth E. Kolko, Lisa Nakamura and Gilbert B. Rodman, (New York, Routledge, 2000), pp. 117-31.

40 Edward H. Sebesta and Euan Hague, 'The U.S. Civil War as a theological struggle: Confederate Christian nationalism and the League of the South', Canadian review of American studies 32 (2002), pp. 253-83.

41 The states that seceded in the 1860s were: Alabama, Arkansas, Florida, Georgia, Louisiana, Mississippi, North Carolina, South Carolina, Tennessee, Texas and Virginia. The four additional states are Oklahoma, Missouri, Kentucky and Maryland. Southern patriot, 'President's note', 4 (1997), p. 26.

42 Alan Colme, Michael Hill, and Edward H. Sebesta, 'The Alan Colme show', NewsTalk 1050 WEVD New York. Broadcast 19 August 1999. Transcript available at http://www.templeofde mocracy.com/WEVD.htm (accessed 25 April 2000). Claiming States' rights is a common geopolitical strategy by US conservative activists.

43 Tony Horwitz, Confederates in the attic: dispatches from the unfinished Civil War (New York, Vintage, 1999), p. 68.

44 In their review of Terry G. Jordan's Trails to Texas: Southern roots of western cattle ranching (Lincoln, University of Nebraska Press, 1981), published in Southwestern bistorical quarterly, 87 (1983), pp. 218-19, proponents of the Celtic thesis Grady McWhiney and Forrest McDonald describe Jordan's analysis as 'invaluable' and 'superb' for the way it 'devastates' Frederick Jackson Turner's Frontier thesis and the 'Hispanic-American' explanation of cattle ranching in the South. Jordan's description of 'Anglo-American cattle herding' is welcomed with the proviso that the activities that Jordan describes are neither English nor American, rather 'Celtic traditions, practiced by the Irish, Scottish, and Welsh herdsmen of the British Isles for many centuries before they appeared in colonial America'. McWhiney also acknowledges Jordan in Cracker culture: Celtic ways in the old South (Tuscaloosa, University of Alabama Press, 1988).

${ }^{45}$ James Michael Hill, Celtic warfare 1595-1763 (Edinburgh, Donald, 1986). For Grady McWhiney's development of the Celtic thesis see e.g. 'The revolution in nineteenth century Alabama agriculture', Alabama review 31 (1978), pp. 3-32; Cracker culture; Grady McWhiney and Perry Jamieson, Attack and die: Civil War military tactics and the Southern heritage (Tuscaloosa, University of Alabama Press, 1982); Grady McWhiney and Forrest McDonald, 'Celtic origins of Southern herding practices', Journal of Southern bistory $\mathbf{5 1}$ (1985), pp. 165-82. These and others are reviewed in detail in Euan Hague, 'Texts as flags: the League of the South and the development of a nationalist intelligentsia in the United States 1975-2001' Hagar: International social science review 3 (2002), 299-339.

46 McWhiney and Jamieson, Attack and die, p. 178. 
47 Jerry Adler and Holly Morris, 'Celts vs. Anglo-Saxons', Newsweek (10 Aug. 1981), p. 70.

48 Rowland Berthoff, rejoinder to Forrest McDonald and Grady McWhiney, 'A response' to "Celtic mist over the South"', Journal of Southern History 52 (1986), p. 549.

49 Rowland Berthoff, 'Celtic mist over the South', Journal of Southern history 52 (1986), p. 525. Also see e.g. Ned Landsman, 'Communications' regarding "The ethnic origins of the American people, 1790", William and Mary quarterly (third series) 41 (1984), pp. 680-81; Donald Harman Akenson, Being had: historians, evidence, and the Irish in North America (Port Credit, Ontario, P. D. Meany, 1985); Elliott J. Gorn, review of McWhiney, Cracker culture, Journal of American bistory 75 (1989), pp. 1290-1291. See Hague, 'Texts as flags' for a fuller analysis.

50 Anthony J. Sheehan, review of Hill Celtic warfare 1595-1763, Irish historical studies 27 (1990), p. 93.

51 Clyde N. Wilson, 'Crackers and roundheads', Chronicles: a magazine of American culture 12 (1988), pp. 22-5; Grady McWhiney, 'The Celtic heritage of the Old South', Chronicles: $a$ magazine of American culture 13 (1989), pp. 12-15.

52 Grady McWhiney, 'Continuity in Celtic warfare', Continuity 2 (1981), pp. 1-18.

53 Hill, 'Kith and kin', p. 34.

54 Barry Reid McCain 'The Anglo-Celts', Southern patriot 3 (1996), p. 35. Echoing McCain, other LS members regularly contribute assessments of the Celtic people and culture of the American South - see e.g. Michael W. Masters, 'We are a people', Southern patriot 2 (1995), pp. 27-8; Roger Busbice, 'The Confederate nation and our Celtic cousins', Southern events 4 (1999), pp. $1,19-20$.

55 Diane Roberts and Michael Hill, 'Interview: The Southern League: hoping the South will rise again', Weekend edition, 5 May 1996, National Public Radio (USA). Transcript available from NPR, Burrelle's Transcripts, PO Box 7, Livingston, NJ07039-0077, USA.

56 See McCain, 'The Anglo-Celts'.

57 See e.g. 'The League of the South grand strategy'. Available at http://www.dixienet.org/ ls-homepg/ls-grand-strategy.html (accessed 18 Jan. 2005).

58 Clyde Wilson, 'After Independence', Southern patriot 4 (1996), p. 27. Available at http:// 216.157.8.33/spatriot/vol3no4/after_independence.html (accessed 26 June 2003). The League of the South has adopted its own grammatical rules; thus 'wont' is purposely spelled without an apostrophe.

59 See e.g. Barry Yeoman, 'The Hispanic diaspora' Mother Jones (July/Aug 2000), pp. 35-41, $76-7$.

60 On many occasions, League of the South rhetoric is eerily close to that of the ruling Boers in Apartheid South Africa, with their assertions of the need to maintain European institutional dominance and cultural authority in their 'homeland'.

${ }^{61}$ Michael Hill, 'The issue of race in the Southern Independence debate'. Available at http:// www.dixienet.org/positions/race.htm (accessed 26 June 2003).

62 Bulmer and Solomos, 'Introduction', pp. 827-8.

63 Forrest McDonald and Grady McWhiney argue, for example, that the southern USA is and always has been populated mainly by persons of Celtic extraction...the sociological/ geographical accounts of Celtic peoples by the Greeks Strabo and Diodorus [read] for all the world like a caricature of our rural neighbours in modern Alabama. In other words, except for variations in technology and dress, descriptions of Celtic social norms spanning two thousand years and more are entirely interchangeable.' See 'In search of Southern roots', Reviews in American history 5 (1977), p. 456. 
${ }^{64}$ For geographical assessment of the Lega Nord, see e.g. John Agnew, 'The rhetoric of regionalism: the Northern League in Italian politics 1983-94', Transactions of the Institute of British Geographers 20 (1995), pp. 156-72; Benito Giordano, 'A place called "Padania"? The Lega Nord and the political representation of northern Italy', European urban and regional studies 6 (1999), pp. 215-30; 'Italian regionalism or "Padanian" nationalism: the political project of the Lega Nord in Italian politics', Political geography 19 (2000), pp. $445-71$.

65 John Agnew and Carlo Brusa, 'New rules for national identity? The Northern League and political identity in contemporary Northern Italy', National identities 1 (1999), p. 124.

Cento A. Bull, 'Ethnicity, racism and the Northern League'. in Italian regionalism, history, identity and politics, ed. C. Levy (Oxford, Berg, 1996), pp. 174-75.

67 Ibid., p. 177

68 Author's fieldnotes extract from interview with a LN councillor in the commune of Varese, 27 Mar 1996.

69 Gilberto Oneto and Gianfranco Pagliarini, 50 buone ragioni per l'Indipendenza (1998). Formerly available at http://www.leganord.org/frames/informazione.htm (accessed 31 Aug 2001).

70 Ibid., emphasis added.

71 See, e.g. Gilberto Oneto, L'invenzione della Padania: la rinascita della comunità più antica d'Europa (Bergamo, Foedus 1997). http://web.tiscali.it/brenna/tdm/letture1.htm (accessed 30 July 2004).

72 Oneto and Pagliarini, 50 buone ragioni per l'Indipendenza.

73 Similar arguments were made by nationalists in the Balkans in the late 1980s and early 1990s. Croats cast Serbs as irrational, backward and barbarous and, by implication, non-European. Similar comments were made by Serbian nationalists about Muslims in Bosnia-Hercegovina and Kosovo. Thanks to Alex Papadopoulos for noting these parallels.

${ }^{74}$ La repubblica, "Giustizia, la Lega in piazza Bossi: "No a Forcolandia" (9 Dec 2001); David Willey, 'Northern League comes out fighting', available at http://www.news.bbc.co.uk/hi/ english/world/europe/newsid_1331000/1331704.stm (accessed 15 May 2001).

75 Umberto Bossi and Daniele Vimercati, Vento dal Nord: la mia lega la mia vita (Milan, Sperling \& Kupfer, 1992), p. 149. Extracomunitari is the word used to describe people who come to Italy from countries outside the EU. It is often used in a derogatory fashion.

76 Author's fieldnotes extract from interview with a LN councillor in the commune of Varese, 27 Mar 1996.

77 Jan Penrose, 'Reification in the name of change: the impact of nationalism on social constructions of nation, people and place in Scotland and the United Kingdom', in Constructions of race, place and nation, ed. Peter Jackson and Jan Penrose (Minneapolis, University of Minnesota Press, 1993), pp. 27-49.

78 Modood, 'Introduction', p. 10

79 Anthony D. Smith, National identity (London, Penguin, 1991), pp. 164, 171.

80 Chris Haylett, 'Illegitimate subjects?: abject whites, neoliberal modernisation, and middle-class multiculturalism', Environment and planning D: society and space 19 (2001), pp. 351-70.

81 Audrey Kobayashi and Linda Peake, 'Racism out of place: thoughts on whiteness and an antiracist geography in the new millennium', Annals of the Association of American Geographers 90 (2000), pp. 392-403.

82 The historical development of the association of Europe with whiteness is assessed by Alastair Bonnett in 'Who was white? The disappearance of non-European white identities and the 
formation of European racial whiteness', Ethnic and racial studies 21 (1998), pp. 1029-55. See also Dyer, White.

83 Kobayashi and Peake, 'Racism out of place'. See also articles in the special issue about race in Professional geographer 54 (2002); and recent debate about whiteness in Area, e.g. Alastair Bonnett, 'Geography, "race", and whiteness: Invisible traditions and current challenges', Area 29 (1997), pp. 193-99; Jackson, 'Constructions of "whiteness"; Mark McGuinness, 'Geography matters? Whiteness and contemporary geography', Area 32 (1999), pp. 225-30.

84 Bobby M. Wilson, 'Critically understanding race-connected practices: a reading of W.E.B. Du Bois and Richard Wright', Professional geographer 54 (2002), p. 39 (emphasis original). 